\title{
INTUICYJNE ROZWIAZYWANIE PROBLEMÓW DECYZYJNYCH Z WYKORZYSTANIEM TEORII SYSTEMÓW SZARYCH
}

DOI: 10.33141/po.2019.12.04

\author{
Marcin Nowak, Arkadiusz Borowiec
}

\section{Wprowadzenie}

W literaturze przedmiotu występuje szereg definicji intuicji. Mianem intuicji określa się pewien szczególny typ poznania, rodzaj wiedzy bądź władzy umysłowej (Rorty, 2005). Według W.H. Agora (1998, s. 32-34), intuicja stanowi sposób myślenia odbywający się na styku świadomości i nieświadomości. Natomiast H. Simon (2013, s. 136) postrzega intuicję jako racjonalny proces, podczas którego umysł przeszukuje pamięć i wcześniejsze doświadczenia dla odnalezienia analogii, które umożliwiają podjęcie właściwych decyzji w nowych okolicznościach. Z kolei J. Parikh i inni (1994) wskazują, że skumulowane poza świadomością podmiotu doświadczenie stanowi istotę intuicji, będącą jedną z form inteligencji. A.P. Wierzbicki (1997, s. 69; 2004). postrzega natomiast intuicję jako quasi-świadomy proces informacyjny odbywający się w ludzkim umyśle, opierający się na wcześniejszych doświadczeniach. W niniejszym opracowaniu przyjęto, że intuicją nazwać można umiejętność formułowania sądów intuicyjnych. Przez sądy intuicyjne rozumie się natomiast sądy nieoparte na innych sądach podmiotu poznania (Nowak, Ziomek, 2019, s. 147).

Zastosowanie intuicji w decyzjach menedżerskich stanowi jedno z ważniejszych zagadnień epistemologii nauk o zarządzaniu, zwłaszcza w odniesieniu do akceptowanych źródeł poznania. Ł. Sułkowski (2015 s. 116) wskazuje również na rozdźwięk między teorią a praktyką zarządzania, przejawiający się m.in. pojawieniem wątpliwych autorytetów zarządzania (guru), budujących swoje stwierdzenia niemal wyłącznie na intuicji. Poznanie może wynikać z dwóch źródeł - rozumu (poznanie logiczne) bądź intuicji (poznanie alogiczne). W ostatnich latach badacze nauk o zarządzaniu podkreślają szczególną rolę procesów poznawczych, których źródła mają charakter pozarozumowy (Simon, 2013; Cleden, 2017; Griffin, 2016). Problematyka intuicji stanowi obecnie jedno $\mathrm{z}$ wiodących zagadnień współczesnego zarządzania (Hodgkinson, Sadler-Smith, 2015; Jędrzejczyk, Kucęba, 2016; Khatri, Ng, 2000). Intuicja odgrywa szczególną rolę $\mathrm{w}$ sytuacjach, $\mathrm{w}$ których menedżer podejmuje decyzje w warunkach dużej niepewności (Luhmann, 2018; Beach, Lipshitz, 2017). Wówczas zawodzi szereg znanych w literaturze metod podejmowania decyzji (Mierzwiak i in., 2018, s. 203-204). W praktyce zarządzania niepewność decyzyjna egzemplifikowana jest poprzez:

- posiadanie niekompletnych informacji dotyczących podejmowanych problemów decyzyjnych,

- małą ilość posiadanych informacji,
- posiadanie informacji o charakterze subiektywnym, obarczonych błędami.

$\mathrm{W}$ przypadku zaistnienia powyższych cech tradycyjne metody podejmowania decyzji, oparte na statystyce, teorii zbiorów przybliżonych czy też logice rozmytej, stają się mało użyteczne (Mierzwiak i in., 2018). W obliczu wskazanych cech charakterystycznych decyzji podejmowanych $\mathrm{w}$ warunkach wysokiej niepewności zauważalny jest brak odpowiedniego instrumentarium metodycznego umożliwiającego wsparcie decydentów (menedżerów). Jednym $\mathrm{z}$ celów teorii zarządzania jest natomiast opracowywanie metod pozwalających obiektywizować proces podejmowania decyzji. Autorzy niniejszego opracowania, w oparciu o zdiagnozowaną niszę teoretyczną, proponują zastosowanie teorii systemów szarych jako podstawy obiektywizacji decyzji, które obecnie z konieczności podejmowane są często w sposób intuicyjny. Teoria systemów szarych stanowi nową metodykę modelowania procesów cechujących się dużą niepewnością, zwłaszcza w odniesieniu do małej ilości informacji i ich subiektywizmu.

W niniejszym opracowaniu założono osiągnięcie dwóch celów - celu teoretycznego oraz celu praktycznego. Celem teoretycznym (poznawczym) w artykule jest przedstawienie nowego szarego modelu klastrowo-decyzyjnego opartego na koncepcji liczb szarych (Grey Numbers). Celem praktycznym (utylitarnym) w artykule jest natomiast przedstawienie działania opracowanego szarego modelu decyzyjnego na przykładzie wyboru normatywnej strategii marketingowej dla przedsiębiorstwa. Dla osiągnięcia celu poznawczego posłużono się metodą analizy dotychczasowego piśmiennictwa (zwłaszcza w odniesieniu do teorii systemów szarych). Dla osiągnięcia celu utylitarnego opracowania wykorzystano szary model decyzyjny".

Wybór strategii marketingowej potraktowany został jako decyzja z dużym udziałem intuicji ze względu na trzy cechy. Po pierwsze, wartości kryteriów w ramach oceny zarówno makrootoczenia, mikrootoczenia, jak i zasobów przedsiębiorstwa mają charakter mocno subiektywny - są zatem obarczone błędami. Po drugie, ocena wielu kryteriów decyzyjnych dotyczących otoczenia przedsiębiorstwa odbywa się w warunkach posiadania bardzo nielicznej bazy empirycznej. Po trzecie, niekompletność posiadanych informacji wynika $z$ faktu, iż skuteczność dzisiejszych decyzji zależy od przyszłych, z założenia niepewnych (niekompletnych) informacji. 


\section{Teoria systemów szarych}

$\mathbf{P}$ oczątki teorii systemów szarych (Grey System Theory) sięgają lat 80. XX w., kiedy to J. Deng $(1982 ; 1989)$ wyłożył podstawy nowej teorii umożliwiającej w sposób ilościowy opisywanie, wyjaśnianie i prognozowanie systemów obarczonych wysokim poziomem niepewności. Przedmiotem teorii systemów szarych jest modelowanie niepewności informacyjnej. W tym kontekście teoria ta stanowi alternatywę dla probabilistyki, teorii zbiorów rozmytych (logiki rozmytej) czy też teorii zbiorów przybliżonych (Mierzwiak i in., 2018, s. 203-204).

Niepewność informacyjna jest swoistą cechą wielu systemów, a zwłaszcza organizacji. Niepewność ta może wynikać bądź z nadmiaru informacji generowanych przez dany system, bądź niedoboru informacji (Karr-Wisniewski, Lu, 2010, s. 1062-1063). W przypadku nadmiaru informacyjnego intensywnie rozwijaną metodologią we wspomaganiu zarządzania jest koncepcja Big Data (La Valle i in., 2011). Obszar stosowalności teorii systemów szarych obejmuje zwłaszcza sytuacje występowania niedoboru informacyjnego - w tym kontekście Grey System Theory stanowi przeciwieństwo metod należących do rodziny Big Data. Ze względu na to, że w przypadku problemów zarządczych ma się do czynienia przede wszystkim z niepewnością informacyjną dotyczącą niedoboru informacyjnego, to teoria systemów szarych zyskuje silnie na popularności aplikacyjnej (Liu i in., 2012, s. 89-104). Grey System Theory znajduje szereg zastosowań zarówno w naukach ekonomicznych, jak i społecznych i technicznych (Delcea, 2015, s. 263-265).

Jednymi $z$ najpopularniejszych $\mathrm{w}$ praktyce narzędzi teorii systemów szarych są tzw. szare modele decyzyjne (Grey Decision-Making Models) (Liu i in., 2017, s. 24). Modele te umożliwiają rozwiązywanie szeregu problemów decyzyjnych, jednak ich największe zalety ujawniają się w przypadku podejmowania decyzji w warunkach wysokiego poziomu niepewności. Niepewność ta przejawia się w szczególności małą ilością informacji o systemie, niekompletnością informacyjną czy też brakiem precyzji we wskazaniach decydentów. W teorii systemów szarych wyróżnia się trzy rodzaje modeli decyzyjnych: oparte na wykorzystaniu liczb szarych (Grey Number Decisions Models), oparte na wykorzystaniu funkcji wybielania wagowego (Grey Target Decisions) oraz oparte na dystrybutywnym rozumieniu szarości (Grey Incidence Decisions). Na przestrzeni ostatnich kilku lat przedstawiono sposób wykorzystania szarych modeli decyzyjnych do m.in.:

- analizy potencjału strategicznego przedsiębiorstwa (Zakeri i in., 2019),

- rozwoju produktów przedsiębiorstwa (Hsiao i in., 2017),

- diagnozy konfliktów w przedsiębiorstwach rodzinnych (Więcek-Janka i in., 2019),

- problemu wyboru dostawców (Haeri, Rezaei, 2019; Rao i in., 2017),

- analizy efektywności oddziałów franczyzowych (Day i in., 2017).
Wśród najbardziej popularnych modeli wypracowanych w ramach teorii systemów szarych, poza modelami decyzyjnymi, zalicza się szare modele prognostyczne (Grey Prediction Model), szare modele relacyjne (Grey Relational Space), szare modele kontrolne (Grey Control Model) oraz szare modele klastrowe (Grey Clustering Model) (Liu i in., 2017).

Modele opracowane $\mathrm{w}$ ramach teorii systemów szarych cechują się uniwersalnością - można je zastosować w rozwiązywaniu szeregu problemów zarządczych. Użyteczność stosowania metod teorii systemów szarych maleje jednak w przypadku zmniejszającego się stopnia niepewności informacyjnej - zwłaszcza w sytuacji gdy posiada się wiele informacji o analizowanym problemie, informacje o nim są kompletne i nie mają charakteru subiektywnego. W takich sytuacjach większą użytecznością cechują się rozwinięte na przestrzeni setek lat metody statystyczne.

\section{Arytmetyka liczb szarych}

$\mathbf{P}$ odstawowym operatorem teorii systemów szarych są liczby szare. Liczbę szarą oznacza się zwyczajowo symbolem $\otimes G$. Istotą liczby szarej jest to, że jej dokładna wartość jest nieznana - znany jest jednak przedział, w którym wartość ta się znajduje. Przedział, w którym występuje liczba szara oznacza się symbolem $\otimes G \in[\underline{G}, \bar{G}]$, gdzie $\underline{G}$ oznacza dolną granicę przedziału, a $\bar{G}$ oznacza górną granicę przedziału. Przykładowo, liczba szara $\otimes G \in[10,17]$ oznacza, że dokładna wartość poszukiwanej liczby nie jest znana, ale wiadome jest, że zawiera się ona w przedziale od 10 do 17.

Definicja 1. Liczbą szarą $\otimes G$ nazywa się liczbę rzeczywistą $d^{\star}$, która spełnia następujący warunek $\left\{\mathrm{d}^{\star} \in[\underline{G}, \bar{G}]\right\}$ $\wedge\{\underline{G} \neq \bar{G}\} \wedge\{(\underline{G} \vee \bar{G}) \neq \pm \infty\}$.

Liczba szara może znajdować się $w$ następujących przedziałach:

- $\otimes G \in[-\infty, \bar{G}]$, gdzie $\bar{G} \neq+\infty$

- $\otimes G \in[\underline{G},+\infty]$, gdzie $\underline{G} \neq-\infty$

- $\otimes G \in[\underline{G}, \bar{G}]$, gdzie $(\underline{\underline{G}} \neq-\infty) \wedge(\bar{G} \neq+\infty) \wedge(\underline{G} \neq \bar{G})$

Jeżeli liczba szara zostaje określona poprzez trzeci $\mathrm{z}$ przedstawionych przedziałów, to taką liczbę nazywa się szarą liczbą interwałową (grey interval number). W literaturze teorii systemów szarych (Liu i in., 2017, s. 35-37) wyróżnia się następujące podstawowe operacje arytmetyczne na szarych liczbach interwałowych:

$$
\begin{aligned}
& \text { - } \otimes G_{1}+\otimes G_{2} \in\left[\underline{G}_{1}+\underline{G}_{2}, \bar{G}_{1}+\bar{G}_{2}\right] \\
& \text { - } \otimes G_{1}-\otimes G_{2} \in\left[\underline{G}_{1}-\bar{G}_{2}, \bar{G}_{1}-\underline{G}_{2}\right] \\
& \text { - } \otimes G_{1} \cdot \otimes G_{2} \in\left[\min \left\{\underline{G}_{1} \underline{G}_{2}, \underline{G}_{1} \bar{G}_{2}, \bar{G}_{1} \underline{G}_{2}, \bar{G}_{1} \bar{G}_{2}\right\},\right. \\
& \left.\max \left\{\underline{G}_{1} \underline{G}_{2}, \underline{G}_{1} \bar{G}_{2}, \bar{G}_{1} \underline{G}_{2}, \bar{G}_{1} \bar{G}_{2}\right\}\right] \\
& \text { - } \otimes G_{1} \div \otimes G_{2} \in\left[\min \left\{\frac{\underline{G}_{1}}{\underline{G}_{2}}, \frac{\underline{G}_{1}}{\bar{G}_{2}}, \frac{G_{1}}{\underline{G}_{2}}, \frac{G_{1}}{\bar{G}_{2}}\right\}, \max \left\{\frac{\underline{G}_{1}}{\underline{G}_{2}}, \frac{\underline{G}_{1}}{\bar{G}_{2}}, \frac{\bar{G}_{1}}{\underline{G}_{2}}, \frac{G_{1}}{G_{2}}\right\}\right] \text {, } \\
& \text { gdzie } \underline{G}_{2} \neq 0, \bar{G}_{2} \neq 0 \\
& \text { - } \otimes G \cdot k \in[k \cdot \underline{G}, \boldsymbol{k} \cdot \bar{G}]
\end{aligned}
$$

Przedstawione operacje arytmetyczne na liczbach szarych stanowią rdzeń istotnej części metod zaliczanych do teorii systemów szarych, w tym modeli decyzyjnych. W oparciu o przedstawione operacje opracowano szary model klastrowo-decyzyjny. 


\section{Wybór strategii marketingowej w przedsiębiorstwach}

$\mathrm{J}$ ednym z najważniejszych problemów decyzyjnych dla każdego przedsiębiorstwa jest wybór strategii konkurowania na rynku (Wrzosek, 2001, s. 41-43). W sensie ogólnym przez strategię rozumieć można plan działań zmierzający do takiego wykorzystania zasobów organizacji, aby w określonych warunkach jej otoczenia osiągać zamierzone cele (Mruk i in., 2015, s. 55). Jeżeli zakres przedmiotowy strategii obejmuje produkty (usługi), ceny, dystrybucję oraz promocję, to taką strategię nazwać można strategią marketingową. W niniejszym opracowaniu zdecydowano się na opracowanie modelu wyboru strategii marketingowej przede wszystkim dlatego, że problem ten powszechnie występuje w każdej organizacji.

Wybór strategii marketingowej wymaga przeprowadzenia szeregu analiz dotyczących zarówno makro- oraz mikrootoczenia, jak i zasobów posiadanych przez przedsiębiorstwo. Tym samym jest to proces o silnym podłożu racjonalnym. W praktyce działalności gospodarczej okazuje się często, że niezależnie od prowadzonych analiz o charakterze logicznym (racjonalnym) o sukcesie wyboru danej strategii marketingowej decyduje intuicja decydentów. O tym, że wybór strategii marketingowej w przedsiębiorstwie można traktować jako decyzję o charakterze w dużej mierze intuicyjnym, decydują następujące przesłanki:

1. Wartości kryteriów w ramach oceny zarówno makrootoczenia, mikrootoczenia, jak i zasobów przedsiębiorstwa mają charakter mocno subiektywny - są zatem obarczone błędami.

2. Ocena wielu kryteriów decyzyjnych dotyczących otoczenia przedsiębiorstwa odbywa się w warunkach posiadania bardzo nielicznej bazy empirycznej.

3. Niekompletność posiadanych informacji wynika $\mathrm{z}$ faktu, iż skuteczność dzisiejszych decyzji zależy od przyszłych, z założenia niepewnych (niekompletnych) informacji.

O ile możliwe jest istotne zredukowanie niepewności decyzyjnej w odniesieniu do przesłanki pierwszej (subiektywnej oceny zasobów przedsiębiorstwa i jego otoczenia) oraz drugiej (nielicznej bazy empirycznej), o tyle niemożliwe jest istotne zredukowanie niepewności decyzyjnej $\mathrm{w}$ odniesieniu do przesłanki trzeciej. O tym, czy dana strategia marketingowa okaże się skuteczna, czy nie, decydują nie historyczne informacje dotyczące otoczenia i wnętrza przedsiębiorstwa, ale ich stany przyszłe. To odniesienie do przyszłości czyni wybór strategii marketingowej decyzją w dużej mierze intuicyjną. W literaturze przedmiotu wyróżnia się szereg klasyfikacji strategii marketingowych. Według klasyfikacji normatywnej wyróżnia się trzy rodzaje strategii (Bielski, 2006, s. 234):

- strategię ekspansji - polegającą przede wszystkim na dynamicznym umocnieniu pozycji rynkowej przedsiębiorstwa $\mathrm{w}$ odniesieniu do pewnych grup produktowych. Realizacja tej strategii wymaga zaangażowania stosunkowo znacznych zasobów, zarówno technicznych, ludzkich, jak i finansowych. Celem strategii ekspansji jest maksymalizacja zysków przedsiębiorstwa w długim okresie. Strategia ta wybierana jest wówczas, gdy potencjał zasobowy przedsiębiorstwa jest znaczny, a rynek, na którym funkcjonują wybrane grupy produktowe, jest atrakcyjny;

- strategię selektywnego rozwoju - polegającą na rozwijaniu wybranych grup produktowych na wybranych rynkach. Celem strategii selektywnego rozwoju jest maksymalizacja zysków przedsiębiorstwa w średnim okresie. Realizacja tej strategii odbywa się szczególnie wówczas, gdy zasoby przedsiębiorstwa mają charakter mocno ograniczony przy jednoczesnej umiarkowanej atrakcyjności rynku, na którym funkcjonują produkty przedsiębiorstwa;

- strategię eksploatacji rynkowej i wycofywania się z rynku - polegającą na maksymalizacji zysków przedsiębiorstwa w krótkim okresie i stopniowym wycofywaniu się z danego rynku. Realizacja tej strategii odbywa się szczególnie wówczas, gdy zasoby przedsiębiorstwa są niewielkie.

W niniejszym opracowaniu przedstawiono model wyboru strategii marketingowej oparty na teorii systemów szarych. Przedstawienie struktury opracowanego modelu wymaga uprzedniego wprowadzenia do problematyki arytmetyki liczb szarych.

\section{Grey Number Decision Model - model formalny}

0 pierając się na arytmetyce liczb szarych oraz metodzie porównań liczb szarych $\mathrm{z}$ wykorzystaniem szarego wskaźnika prawdopodobieństwa (the grey possibility degree) $)^{2}$, autorzy opracowania proponują nowy szary model klastrowo-decyzyjny do zastosowania w wyborze normatywnej strategii marketingowej przedsiębiorstwa. Ogólną interpretację graficzną modelu przedstawiono na rysunku 1.

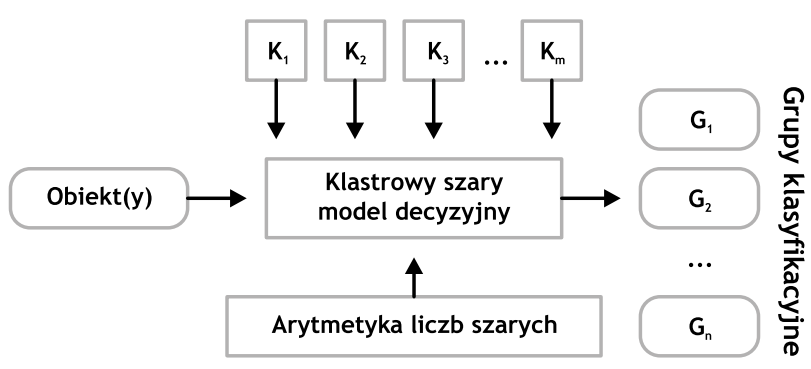

Rys. 1. Interpretacja graficzna klastrowego szarego modelu decyzyjnego

Źródło: opracowanie własne

Zgodnie z proponowanym modelem, wobec każdego $\mathrm{z}$ analizowanych obiektów (którymi mogą być na przykład przedsiębiorstwa), uwzględniając założony zbiór kryteriów decyzyjnych (od $K_{1}$ do $K_{\mathrm{m}}$ ), podejmuje się decyzje co do ich przyporządkowania do poszczególnych grup klasyfikacyjnych - klastrów (od $G_{1}$ do $G_{\mathrm{n}}$ ).

Procedura postępowania zgodnie $\mathrm{z}$ proponowanym klastrowym szarym modelem decyzyjnym wspierającym intuicyjne decyzje menedżerów składa się z następujących kroków. 
Krok 1. Określenie kryteriów decyzyjnych wyboru strategii normatywnej rozwoju przedsiębiorstwa

W opracowanym modelu proponuje się wyszczególnienie trzech rodzajów kryteriów - dotyczących kolejno atrakcyjności makrootoczenia, atrakcyjności mikrootoczenia oraz zasobów przedsiębiorstwa. $\mathrm{W}$ tabeli 1 przedstawiono proponowany zestaw kryteriów w podziale na poszczególne grupy rodzajowe.

\section{Krok 2. Określenie wag kryteriów decyzyjnych}

Wagi dla kolejnych kryteriów decyzyjnych wyznaczone zostaną zgodnie $\mathrm{z}$ formułą

$$
\otimes w_{\mathrm{j}}=\frac{1}{K}\left(\otimes w_{j}^{1}+\otimes w_{j}^{2}+\ldots+\otimes w_{j}^{K}\right)
$$

gdzie $\otimes w_{j}^{K}$ jest wagą $j$-tego kryterium decyzyjnego wskazaną przez $K$-tego eksperta.

Waga poszczególnych kryteriów decyzyjnych stanowi zatem średnią arytmetyczną ocen ekspertów. Ze względów technicznych nie istnieje żadne ograniczenie liczności ekspertów. Ze względów merytorycznych natomiast wskazać można, że im większa będzie liczba ekspertów, tym mniejszy poziom subiektywizmu, a więc niepewności informacyjnej. Proponowaną skalę wartości kryteriów decyzyjnych wyrażoną za pomocą liczb szarych przedstawiono w tabeli 2 .

Zgodnie $\mathrm{z}$ opracowanym modelem, eksperci na pytania o ważność poszczególnych kryteriów decyzyjnych odpowiadają według pięciostopniowej skali lingwistycznej (możliwe jest również zastosowanie innej skali, np. cztero- lub siedmiostopniowej). Założono, że waga każdego $\mathrm{z}$ kryteriów ma zakres wartości od 0 do 1 . Zakres ten podzielono na pięć równych przedziałów, które przedstawiono $\mathrm{z}$ wykorzystaniem liczb szarych o jednakowych zakresach (różnicach między górną a dolną granicą liczby szarej).

\section{Krok 3. Wyznaczenie wartości kolejnych atrybutów decyzyjnych}

$\mathrm{W}$ proponowanym modelu wystąpić musi $n+1$ stopniowa skala lingwistyczna, gdzie $n$ oznacza liczbę możliwych alternatywnych strategii rozwoju. Zważając na to, że wynikiem przedstawianego modelu decyzyjnego jest sformułowanie rekomendacji dotyczącej realizacji strategii ekspansji, selektywnego rozwoju bądź eksploatacji rynkowej i stopniowego wycofywania się z rynku, w modelu zaproponowano wykorzystanie 4-stopniowej skali lingwistycznej (tzw. skali wymuszonego wyboru). $\mathrm{W}$ tabeli 3 przedstawiono procedurę przypisania każdej $\mathrm{z}$ ocen lingwistycznych wartości atrybutu w postaci liczby szarej.

Ocena wartości poszczególnych atrybutów przez ekspertów często ma charakter intuicyjny. Przedstawienie do oceny atrybutów wyrażonych na skali lingwistycznej stanowi $\mathrm{z}$ jednej strony sposób na obiektywizację ilościową intuicji ekspertów, a z drugiej strony umożliwia agregację i analizę ich ocen $\mathrm{z}$ wykorzystaniem arytmetyki liczb szarych.

Wartości kolejnych atrybutów decyzyjnych wyznacza się zgodnie $\mathrm{z}$ wzorem

$$
\otimes G_{\mathrm{j}}=\frac{1}{K}\left(\otimes G_{j}^{1}+\otimes G_{j}^{2}+\ldots+\otimes G_{j}^{K}\right)
$$

gdzie $\otimes G_{j}^{K}$ jest wartością atrybutu dla $j$-tego kryterium decyzyjnego wskazaną przez $K$-tego eksperta.

Kolejnym krokiem jest opracowanie szarego wektora decyzyjnego.

Tabela 1. Kryteria wyboru strategii normatywnej

\begin{tabular}{|l|l|l|}
\hline \multicolumn{1}{|c|}{ Atrakcyjność makrootoczenia } & \multicolumn{1}{|c|}{ Atrakcyjność mikrootoczenia } & \multicolumn{1}{|c|}{ Zasoby przedsiębiorstwa } \\
\hline czynniki polityczno-prawne $\left(K_{1}\right)$ & klienci $\left(K_{5}\right)$ & zasoby rzeczowe $\left(K_{\mathbf{9}}\right)$ \\
czynniki ekonomiczno-gospodarcze $\left(K_{\mathbf{2}}\right)$ & dostawcy $\left(K_{\mathbf{6}}\right)$ & zasoby finansowe $\left(K_{10}\right)$ \\
czynniki społeczno-kulturowe $\left(K_{\mathbf{3}}\right)$ & obecna i potencjalna konkurencja $\left(K_{7}\right)$ & zasoby ludzkie $\left(K_{11}\right)$ \\
czynniki technologiczne $\left(K_{4}\right)$ & substytuty $\left(K_{\mathbf{8}}\right)$ & stan zamówień na produkty i usługi $\left(K_{12}\right)$ \\
\hline
\end{tabular}

Źródto: opracowanie wtasne

Tabela 2. Skala wartości ważności kryteriów decyzyjnych wyrażona za pomocą liczb szarych

\begin{tabular}{|c|c|}
\hline Ocena lingwistyczna & Waga kryterium $\otimes w$ \\
\hline Zdecydowanie nieważny & {$[0,0 ; 0,2]$} \\
\hline Raczej nieważny & {$[0,2 ; 0,4]$} \\
\hline Średnio ważny & {$[0,4 ; 0,6]$} \\
\hline Raczej ważny & {$[0,6 ; 0,8]$} \\
\hline Zdecydowanie ważny & {$[0,8 ; 1,0]$} \\
\hline
\end{tabular}

Źródto: opracowanie własne
Tabela 3. Proces przypisania wartości atrybutu w postaci liczby szarej $\otimes G$ ocenom lingwistycznym

\begin{tabular}{|c|c|}
\hline $\begin{array}{c}\text { Ocena lingwistyczna } \\
\text { atrybutu }\end{array}$ & $\begin{array}{c}\text { Wartość atrybutu w postaci } \\
\text { liczby szarej } \otimes \boldsymbol{G}\end{array}$ \\
\hline Bardzo atrakcyjny & {$[0,0 ; 2,5]$} \\
\hline Raczej atrakcyjny & {$[2,5 ; 5,0]$} \\
\hline Raczej nieatrakcyjny & {$[5,0 ; 7,5]$} \\
\hline Bardzo nieatrakcyjny & {$[7,5 ; 10,0]$} \\
\hline
\end{tabular}

Źródło: opracowanie wtasne 
Krok 4. Opracowanie szarego

wektora decyzyjnego

$$
D=\left(\otimes G_{1}, \otimes G_{2}, \ldots, \otimes G_{m}\right)
$$

gdzie $\otimes G_{j}$ jest wartością zmiennej wyrażonej w postaci liczb szarych.

\section{Krok 5. Opracowanie ważonego}

szarego wektora decyzyjnego

$$
\begin{aligned}
D^{*} & =\left(\otimes V_{1}, \otimes V_{2}, \ldots, \otimes V_{m}\right) \\
\text { gdzie }=\otimes V_{j} & =\otimes G_{j} \times \otimes w_{j}
\end{aligned}
$$

Krok 6. Obliczenie łącznej oceny ważonej

$$
\otimes R=\left[\Sigma_{i=1}^{m} \underline{V}_{i}, \Sigma_{i=1}^{m} \bar{V}_{i}\right]
$$

Krok 7. Opracowanie ważonych szarych wektorów referencyjnych

Do obliczenia ważonych szarych wektorów referencyjnych zamiast wartości $\otimes G_{j}$ stosuje się liczby szare oznaczające kolejne progi ocen skali lingwistycznej z tabeli 3, tj. $[7,5 ; 10,0],[5,0 ; 7,5],[2,5 ; 5,0],[0,0 ; 2,5]$. W ten sposób uzyskuje się wzory (6) - (9):

$$
\begin{aligned}
G_{r e f}^{1} & =\left[[7,5 ; 10,0] \times \otimes w_{j}\right] \\
G_{r e f}^{2} & =\left[[5,0 ; 7,5] \times \otimes w_{j}\right] \\
G_{r e f}^{3} & =\left[[2,5 ; 5,0] \times \otimes w_{j}\right] \\
G_{r e f}^{4} & =\left[[0,0 ; 2,5] \times \otimes w_{j}\right]
\end{aligned}
$$

Krok 8. Wyznaczenie wartości referencyjnych liczb szarych

$$
\begin{aligned}
& \otimes G_{r e f 1}=\left[7,5 \sum_{i=1}^{m} \underline{w}_{i}, 10,0 \sum_{i=1}^{m} \bar{w}_{i}\right] \\
& \otimes G_{r e f 2}=\left[5,0 \sum_{i=1}^{m} \underline{w}_{i}, 7,5 \sum_{i=1}^{m} \bar{w}_{i}\right] \\
& \otimes G_{r e f 3}=\left[2,5 \sum_{i=1}^{m} \underline{w}_{i}, 5,0 \sum_{i=1}^{m} \bar{w}_{i}\right] \\
& \otimes G_{r e f 4}=\left[0,0 \sum_{i=1}^{m} \underline{w}_{i}, 2,5 \sum_{i=1}^{m} \bar{w}_{i}\right]
\end{aligned}
$$

Między wartościami referencyjnych liczb szarych zachodzić musi następująca zależność:

$$
\otimes G_{r e f 1}>\otimes G_{r e f 2}>\otimes G_{r e f 3}>\otimes G_{r e f 4}
$$

Krok 9. Wyznaczenie pozycji łącznej oceny ważonej w nierówności (14)

Pozycja łącznej oceny ważonej $\otimes R$ w nierówności (14) decyduje o tym, którą strategię normatywną powinno realizować przedsiębiorstwo. W tabeli 4 przedstawiono sposób wyboru strategii na podstawie wyznaczonego wskaźnika $\otimes R$.
Porównanie $\otimes R$ z poszczególnymi wartościami $\otimes G_{\text {ref } 1}$, $\otimes G_{r e f 2}, \otimes G_{r e f 3}$ oraz $\otimes G_{r e f 4}$ wymaga wyznaczenia szarego współczynnika prawdopodobieństwa między porównywanymi liczbami szarymi. Zgodnie z tym wskaźnikiem, prawdopodobieństwo, że jedna liczba szara $\left(\otimes G_{2}\right)$ jest większa od drugiej liczby szarej $\left(\otimes G_{1}\right)$, wyznacza się według następującego wzoru (Eshtaiwi i in., 2017):

$$
P\left\{\otimes G_{1} \leq \otimes G_{2}\right\}=\frac{\max \left[0, L^{\star}-\max \left(0, G_{1}-G_{2}\right)\right.}{L^{\star}}
$$

gdzie $L^{\star}=L\left(\otimes G_{1}\right)+L\left(\otimes G_{2}\right)$

\section{Przykład zastosowania Grey Number Decision Model}

0 pracowany model wyboru normatywnej strategii marketingowej (strategii rozwoju) zostanie przedstawiony na przykładzie hipotetycznego przedsiębiorstwa zajmującego się produkcją okien i drzwi. Dla określenia strategii marketingowej dla przedsiębiorstwa posłużono się zestawem kryteriów decyzyjnych przedstawionych w tabeli 1 - dotyczących kolejno atrakcyjności makrootoczenia, mikrootoczenia oraz zasobów posiadanych przez przedsiębiorstwo (krok 1 proponowanej procedury). Kolejnym etapem proponowanego modelu było określenie wag kryteriów decyzyjnych (krok 2). Założono, że w określeniu wag poszczególnych kryteriów udział wzięło 3 ekspertów (liczba ekspertów w opracowanej metodzie może być dowolna). W tabeli 5 zestawiono rezultaty procesu ważenia kryteriów decyzyjnych.

Wśród najważniejszych kryteriów wyboru strategii rozwoju eksperci wskazali posiadane zasoby finansowe [0,800; 1,000], atrakcyjność czynników ekonomiczno-gospodarczych $[0,733 ; 0,933]$, atrakcyjność rynku ze względu na siłę przetargową dostawców [0,733; 0,933] oraz atrakcyjność rynku ze względu na obecną i potencjalną konkurencję [0,733; 0,933].

Trzecim krokiem opracowanego modelu było przypisanie wartości w poszczególnych kryteriach dla analizowanego przedsiębiorstwa. W procesie tym również uczestniczyło 3 ekspertów. Wyniki procesu przypisania wartości poszczególnym kryteriom decyzyjnym przedstawiono w tabeli 6 .

Zważając na przydzielone w poszczególnych kryteriach decyzyjnych wartości, uzyskuje się następujący szary wektor decyzyjny (grey decision vector) (krok 4):

$$
\begin{gathered}
D=\{[2,500 ; 5,000],[5,833 ; 8,333],[3,333 ; 5,833], \\
\quad[5,833 ; 8,333],[5,000 ; 7,500],[2,500 ; 5,000], \\
\quad[1,667 ; 4,167],[6,667 ; 9,167],[5,833 ; 8,333], \\
[1,667 ; 4,167],[3,333 ; 5,833],[5,833 ; 8,333]\}
\end{gathered}
$$

Tabela 4. Sposób wyboru strategii normatywnej na podstawie wskaźnika $\otimes R$

\begin{tabular}{|c|l|}
\hline Pozycja w nierówności (14) & \multicolumn{1}{|c|}{ Wybór normatywnej strategii marketingowej } \\
\hline$\otimes R \in\left\langle\otimes G_{\text {ref } 2} ; \otimes G_{\text {ref } 1}>\right.$ & Strategia ekspansji \\
\hline$\otimes R \in\left\langle\otimes G_{r e f 3} ; \otimes G_{\text {ref } 2}>\right.$ & Strategia selektywnego rozwoju \\
\hline$\otimes R \in\left\langle\otimes G_{r e f 4} ; \otimes G_{\text {ref } 3}>\right.$ & Strategia eksploatacji rynkowej i stopniowego wycofywania się \\
\hline
\end{tabular}

Źródło: opracowanie własne 
Tabela 5. Wagi kryteriów decyzyjnych

\begin{tabular}{|c|c|c|c|c|}
\hline Kryterium $\left(\boldsymbol{K}_{\boldsymbol{i}}\right)$ & Ekspert 1 & Ekspert 2 & Ekspert 3 & $\otimes \boldsymbol{w}_{j}$ \\
\hline czynniki polityczno-prawne $\left(\boldsymbol{K}_{\mathbf{1}}\right)$ & {$[0,4 ; 0,6]$} & {$[0,4 ; 0,6]$} & {$[0,2 ; 0,4]$} & {$[0,333 ; 0,533]$} \\
\hline czynniki ekonomiczno-gospodarcze $\left(\boldsymbol{K}_{\mathbf{2}}\right)$ & {$[0,8 ; 1,0]$} & {$[0,8 ; 1,0]$} & {$[0,6 ; 0,8]$} & {$[0,733 ; 0,933]$} \\
\hline czynniki społeczno-kulturowe $\left(\boldsymbol{K}_{\mathbf{3}}\right)$ & {$[0,2 ; 0,4]$} & {$[0,4 ; 0,6]$} & {$[0,2 ; 0,4]$} & {$[0,267 ; 0,467]$} \\
\hline czynniki technologiczne $\left(\boldsymbol{K}_{\mathbf{4}}\right)$ & {$[0,0 ; 0,2]$} & {$[0,2 ; 0,4]$} & {$[0,0 ; 0,2]$} & {$[0,067 ; 0,267]$} \\
\hline klienci $\left(\boldsymbol{K}_{\mathbf{5}}\right)$ & {$[0,6 ; 0,8]$} & {$[0,8 ; 1,0]$} & {$[0,8 ; 1,0]$} & {$[0,733 ; 0,933]$} \\
\hline dostawcy $\left(\boldsymbol{K}_{\mathbf{6}}\right)$ & {$[0,6 ; 0,8]$} & {$[0,4 ; 0,6]$} & {$[0,8 ; 1,0]$} & {$[0,600 ; 0,800]$} \\
\hline obecna i potencjalna konkurencja $\left(\boldsymbol{K}_{\mathbf{7}}\right)$ & {$[0,6 ; 0,8]$} & $[0,8 ; 1,0]]$ & {$[0,8 ; 1,0]$} & {$[0,733 ; 0,933]$} \\
\hline substytuty $\left(\boldsymbol{K}_{\mathbf{8}}\right)$ & {$[0,2 ; 0,4]$} & {$[0,2 ; 0,4]$} & {$[0,0 ; 0,2]$} & {$[0,067 ; 0,867]$} \\
\hline zasoby rzeczowe $\left(\boldsymbol{K}_{\mathbf{9}}\right)$ & {$[0,8 ; 1,0]$} & {$[0,6 ; 0,8]$} & {$[0,6 ; 0,8]$} & {$[0,667 ; 0,867]$} \\
\hline zasoby finansowe $\left(\boldsymbol{K}_{\mathbf{1 0}}\right)$ & {$[0,8 ; 1,0]$} & {$[0,8 ; 1,0]$} & {$[0,8 ; 1,0]$} & {$[0,800 ; 1,000]$} \\
\hline zasoby ludzkie $\left(\boldsymbol{K}_{\mathbf{1 1}}\right)$ & {$[0,8 ; 1,0]$} & {$[0,6 ; 0,8]$} & {$[0,4 ; 0,6]$} & {$[0,600 ; 0,800]$} \\
\hline stan zamówień na produkty i usługi $\left(\boldsymbol{K}_{\mathbf{1 2}}\right)$ & {$[0,6 ; 0,8]$} & {$[0,6 ; 0,8]$} & {$[0,8 ; 1,0]$} & {$[0,667 ; 0,867]$} \\
\hline
\end{tabular}

Źródto: opracowanie własne

Tabela 6. Wartości w poszczególnych kryteriach decyzyjnych

\begin{tabular}{|c|c|c|c|c|}
\hline Kryterium $\left(\boldsymbol{K}_{\boldsymbol{i}}\right)$ & Ekspert 1 & Ekspert 2 & Ekspert 3 & $\otimes G_{j}$ \\
\hline czynniki polityczno-prawne $\left(\boldsymbol{K}_{\mathbf{1}}\right)$ & {$[2,5 ; 5,0]$} & {$[2,5 ; 5,0]$} & {$[2,5 ; 5,0]$} & {$[2,500 ; 5,000]$} \\
\hline czynniki ekonomiczno-gospodarcze $\left(\boldsymbol{K}_{\mathbf{2}}\right)$ & {$[5,0 ; 7,5]$} & {$[7,5 ; 10,0]$} & {$[5,0 ; 7,5]$} & {$[5,833 ; 8,333]$} \\
\hline czynniki społeczno-kulturowe $\left(\boldsymbol{K}_{\mathbf{3}}\right)$ & {$[2,5 ; 5,0]$} & {$[2,5 ; 5,0]$} & {$[5,0 ; 7,5]$} & {$[3,333 ; 5,833]$} \\
\hline czynniki technologiczne $\left(\boldsymbol{K}_{\mathbf{4}}\right)$ & {$[5,0 ; 7,5]$} & {$[5,0 ; 7,5]$} & {$[7,5 ; 10,0]$} & {$[5,833 ; 8,333]$} \\
\hline klienci $\left(\boldsymbol{K}_{\mathbf{5}}\right)$ & {$[5,0 ; 7,5]$} & {$[5,0 ; 7,5]$} & {$[5,0 ; 7,5]$} & {$[5,000 ; 7,500]$} \\
\hline dostawcy $\left(\boldsymbol{K}_{\mathbf{6}}\right)$ & {$[2,5 ; 5,0]$} & {$[2,5 ; 5,0]$} & {$[2,5 ; 5,0]$} & {$[2,500 ; 5,000]$} \\
\hline zasoby rzeczowe $\left(\boldsymbol{K}_{\mathbf{9}}\right)$ & {$[0,0 ; 2,5]$} & {$[2,5 ; 50]$} & {$[2,5 ; 5,0]$} & {$[1,667 ; 4,167]$} \\
\hline obecna i potencjalna konkurencja $\left(\boldsymbol{K}_{\mathbf{7}}\right)$ & {$[7,5 ; 10,0]$} & {$[7,5 ; 10,0]$} & {$[5,0 ; 7,5]$} & {$[6,667 ; 9,167]$} \\
\hline zasoby finansowe $\left(\boldsymbol{K}_{\mathbf{1 0}}\right)$ & {$[5,0 ; 7,5]$} & {$[7,5 ; 10,0]$} & {$[5,0 ; 7,5]$} & {$[5,833 ; 8,333]$} \\
\hline zasoby ludzkie $\left(\boldsymbol{K}_{\mathbf{1 1}}\right)$ & {$[2,5 ; 5,0]$} & {$[2,5 ; 5,0]$} & {$[0,0 ; 2,5]$} & {$[1,667 ; 4,167]$} \\
\hline ztan zamówień na produkty i usługi $\left(\boldsymbol{K}_{\mathbf{1 2}}\right)$ & {$[2,5 ; 5,0]$} & {$[2,5 ; 5,0]$} & {$[5,0 ; 7,50]$} & {$[3,333 ; 5,833]$} \\
\hline
\end{tabular}

Źródło: opracowanie własne

Piątym krokiem proponowanej procedury jest wyznaczenie ważonego szarego wektora decyzyjnego (weighted grey decision vector). Wektor ten dla badanego przedsiębiorstwa przyjmuje następującą postać:

$$
\begin{gathered}
D^{\star}=\{[0,833 ; 2,667],[4,278 ; 7,778],[0,889 ; 2,722], \\
{[0,389 ; 2,222],[3,667 ; 7,000],[1,500 ; 4,000],} \\
{[1,222 ; 3,889],[0,444 ; 2,444],[3,889 ; 7,222],} \\
[1,333 ; 4,167],[2,000 ; 4,667],[3,889 ; 7,222]\}
\end{gathered}
$$

Szóstym krokiem opracowanej procedury $\otimes R$ jest wyznaczenie łącznej oceny ważonej $\otimes R$. Wyznaczając ze wzoru (5), uzyskano $\otimes R=[24,333 ; 56,000]$. Siódmy krok procedury polega natomiast na porównaniu liczby $\otimes R$ z wartościami szarych liczb referencyjnych $\otimes G_{\text {ref1 }}$, $\otimes G_{\text {ref2 }}, \otimes G_{\text {ref3 }}, \otimes G_{\text {ref4 }}(8$ krok procedury). Parametry wyznaczonych wektorów referencyjnych, zgodnie z wzorami (10)-(13), przedstawiają się następująco:

- $G_{r e f}^{1}=\{[2,500 ; 5,333],[5,500 ; 9,333],[2,000 ; 4,667]$,

[0,500; 2,667], [5,500; 9,333], [4,500; 8,000],

[5,500; 9,333], [0,500; 2,667], [5,000; 8,667],

$[6,000 ; 10,000],[4,500 ; 8,000],[5,000 ; 8,667]\}$

- $G_{r e f}^{2}=\{[1,667 ; 4,000],[3,667 ; 7,000],[1,333 ; 3,500]$,

$[0,333 ; 2,000],[3,667 ; 7,000],[3,000 ; 6,000]$,

$[3,667 ; 7,000],[0,333 ; 2,000],[3,333 ; 6,500]$,

$[4,000 ; 7,500],[3,000 ; 6,000],[3,333 ; 6,500]\}$ 
- $G_{r e f}^{3}=\{[0,833 ; 2,667],[1,833 ; 4,667],[0,667 ; 2,333]$,

$[0,167 ; 1,333],[1,833 ; 4,667] ;[1,500 ; 4,000]$,

[1,833; 4,667], [0,167; 1,333], [1,667;4,333],

$[2,000 ; 5,000],[1,500 ; 4,000],[1,667 ; 4,333]\}$

- $G_{r e f}^{4}=\{[0 ; 1,333],[0 ; 2,333],[0 ; 1,167],[0 ; 0,667]$,

$[0 ; 2,333],[0 ; 2,000],[0 ; 2,333],[0 ; 0,667],[0 ; 2,167]$,

$[0 ; 2,500],[0 ; 2,000],[0 ; 2,167]\}$

W ostatnim, dziewiątym kroku proponowanej procedury, na podstawie wyznaczonych wektorów referencyjnych, określono ich średnie łączne oceny ważone $\otimes R$ :

- $\otimes R_{r e f}^{1}[47,000 ; 86,667]$,

- $\otimes R_{r e f}^{2}[31,333 ; 65,000]$,

- $\otimes R_{r e f}^{3}[15,667 ; 43,333]$,

• $\otimes R_{r e f}^{4}[0,000 ; 21,667]$.

Korzystając z wzoru (15), określono, że łączna ocena ważona $\left.\otimes \mathrm{R} \in<\otimes \mathrm{G}_{\text {ref } 3} ; \otimes \mathrm{G}_{\text {ref } 2}\right)$. Zgodnie $\mathrm{z}$ tabelą 4, oznacza to, że przedsiębiorstwo powinno zastosować strategię selektywnego rozwoju.

\section{Podsumowanie}

$J$ ednym z największych problemów współczesnego zarządzania jest konieczność podejmowania decyzji w warunkach permanentnej niepewności. Uwarunkowania te sprawiają, że menedżerowie $\mathrm{w}$ wielu decyzjach opierają się na swojej intuicji. Brak jest natomiast metod, które stanowiłyby wsparcie dla menedżerów w obiektywizacji procesów decyzyjnych. W artykule wskazano teorię systemów szarych jako źródło szeregu metod (decyzyjnych, relacyjnych, predykcyjnych), które umożliwiają prowadzenie analiz ilościowych w sytuacjach wysokiego poziomu niepewności. W niniejszym opracowaniu przedstawiono autorski, oparty na teorii systemów szarych, model klastrowo-decyzyjny i zaprezentowano przykład jego wykorzystania w wyborze normatywnej strategii marketingowej przedsiębiorstwa. Zastosowanie nowego modelu pozwoliło uzyskać szereg korzyści. Wśród najważniejszych z nich należy wskazać: możliwość uwzględnienia subiektywnych ocen ekspertów dotyczących potencjału zasobów przedsiębiorstwa oraz atrakcyjności poszczególnych komponentów makro- i mikrootoczenia, zastosowanie naturalnej dla ekspertów branżowych lingwistycznej skali ocen poszczególnych kryteriów decyzyjnych i ich wag, czy też zaproponowane jednoznacznej rekomendacji w zakresie wyboru strategii marketingowej.

Opracowany model pozwala na obiektywizację szeregu decyzji menedżerskich, które w obliczu braku adekwatnych narzędzi podejmowane są często w sposób intuicyjny. Użyteczność zarówno przedstawionego modelu, jak i szeregu innych modeli zaliczanych do teorii systemów szarych wzrasta wraz ze wzrastającym poziomem niepewności, związanym przede wszystkim z małą ilością informacji, ich niekompletnością oraz subiektywnością.

W przypadku gdy menedżerowie posiadają dużą ilość informacji związanych $\mathrm{z}$ podejmowanymi problemami decyzyjnymi, informacje te są kompletne lub gdy wartości poszczególnych atrybutów decyzyjnych mają charakter obiektywny, to większą użytecznością cechują się modele decyzyjne oparte na statystyce.
Ważność podjętej problematyki wynika $\mathrm{z}$ faktu, że w naukach o zarządzaniu często zdarzają się sytuacje, w których poziom niepewności jest wysoki, a baza informacyjna wąska. Artykuł stanowi zatem przyczynek do dalszych badań związanych z obiektywizacją intuicyjnych decyzji menedżerskich na różnych polach zarządzania organizacją.

\section{dr inż. Marcin Nowak \\ Politechnika Poznańska \\ Wydział Inżynierii Zarządzania \\ ORCID: 0000-0001-5005-7820 \\ e-mail: marcin.nowak@put.poznan.pl}

\section{dr hab. inż. Arkadiusz Borowiec, prof. uczelni \\ Politechnika Poznańska \\ Wydział Inżynierii Zarządzania \\ ORCID: 0000-0002-6897-5803 \\ e-mail: arkadiusz.borowiec@put.poznan.pl}

\section{Przypisy}

1) Publikacja została sfinansowana ze środków na działalność statutową Wydziału Inżynierii Zarządzania Politechniki Poznańskiej, z grantu DS Młodzi pt. „Elementy epistemologii nauk o zarządzaniu", nr 11/142/DSMK/1000. Kierownik tematu dr inż. Marcin Nowak.

2) Po raz pierwszy zastosowanych przez Li i in. (2007) w modelach decyzyjnych.

\section{Bibliografia}

[1] Agor W.H. (1998), Intuicja w organizacji. Jak twórczo przewodzić i zarządzać, Wydawnictwo Profesjonalnej Szkoły Biznesu, Kraków.

[2] Beach L.R., Lipshitz R. (2017), Why Classical Decision Theory is an Inappropriate Standard for Evaluating and Aiding Most Human Decision Making, „Decision Making in Aviation", Vol. 85, pp. 835-847.

[3] Bielski I. (2006), Wspótczesny marketing. Filozofia, strategie, instrumenty, Wydawnictwo Studio Emka, Warszawa.

[4] Cleden D. (2017), Managing Project Uncertainty, Routledge, London.

[5] Day J.D., Wang C.N., Dang H.S. (2017), Predicting of the Performance of Franchise Industry Using Grey Models-case Study in United States, „2017 International Conference on System Science and Engineering (ICSSE)", pp. 617-620.

[6] Delcea C. (2015), Grey Systems Theory in Economics - A Historical Applications Review, „Grey Systems: Theory and Application”, Vol. 5, No. 2, pp. 263-276.

[7] Deng J. (1982), Grey Control System, „Journal of Huazhong University of Science and Technology", Vol. 3, No. 9, pp. 288-294.

[8] Deng J. (1989), Introduction to Grey System Theory, „The Journal of Grey System", Vol. 1, No. 1, pp. 1-24. 
[9] Eshtaiwi M.I., Badi I.A., Abdulshahed A.M., Erkan T.E. (2017), Assessment of Airport Performance Using the Grey Theory Method: A Case Study in Libya, „Grey Systems: Theory and Application", Vol. 7, No. 3, pp. 426-436.

[10] Griffin R.W. (2016), Fundamentals of Management, Eight Edition, Cengage Learning, Boston.

[11] Haeri S.A.S., Rezaei J. (2019), A Grey-based Green Supplier Selection Model for Uncertain Environments, „Journal of Cleaner Production", Vol. 221, pp. 768-784.

[12] Hodgkinson G.P., Sadler-Smith E. (2015), Intuition, Wiley Encyclopedia of Management, pp. 1-2.

[13] Hsiao S.W., Lin H.H., Ko Y.C. (2017), Application of Grey Relational Analysis to Decision-Making during Product Development, „Eurasia Journal of Mathematics, Science and Technology Education", Vol. 13, No. 6, pp. 2581-2600.

[14] Jędrzejczyk W., Kucęba R. (2016), The Intuition in Management-Established Knowledge and Perspective of Evolution, [in:] F. Bylok, A. Tangl (eds.), The Role of Management Functions in Successful Enterprise Performance, Agroinform Publishing House, Budapest, pp. 147-156.

[15] Karr-Wisniewski P., Lu Y. (2010), When More is too Much: Operationalizing Technology Overload and Exploring its Impact on Knowledge Worker Productivity, „Computers in Human Behavior”, Vol. 26, No. 5, pp. 1061-1072.

[16] Khatri N., Ng H.A. (2000), The Role of Intuition in Strategic Decision Making, „Human Relations”, Vol. 53, No. 1, pp. 57-86.

[17] LaValle S., Lesser E., Shockley R., Hopkins M.S., Kruschwitz N. (2011), Big Data, Analytics and the Path from Insights to Value, „MIT Sloan Management Review”, Vol. 52, No. 2, pp. 21-32.

[18] Li G.D., Yamaguchi D., Nagai M. (2007), A Grey-based Decision-making Approach to the Supplier Selection Problem, „Mathematical and Computer Modelling”, Vol. 46, No. 3-4, , pp. 573-581.

[19] Liu S., Forrest J., Yang Y. (2012), A Brief Introduction to Grey Systems Theory, „Grey Systems: Theory and Application", Vol. 2, No. 2, pp. 89-104.

[20] Liu S., Yang Y., Forrest J. (2017), Grey Data Analysis, Springer, Berlin.

[21] Luhmann N. (2018), Organization and Decision, Cambridge University Press, Cambridge.

[22] Mierzwiak R., Xie N., Nowak M. (2018), New Axiomatic Approach to the Concept of Grey Information, "Grey Systems: Theory and Application”, Vol. 8, No. 2, pp. 199-209.

[23] Mruk H., Pilarczyk B., Sławińska M. (2015), Marketing. Koncepcje-strategie-trendy, Wydawnictwo Uniwersytetu Ekonomicznego w Poznaniu, Poznań.

[24] Nowak M., Ziomek J. (2019), Intuitive and Rational Cognition in the Theory and Practice of Management Sciences, „Problemy Zarządzania”, Nr 17(2), s. 142-154.

[25] Parikh J., Neubauer F.F., Lank A.G. (1994), Intuition: The New Frontier of Management, Blackwell.

[26] Rao C., Goh M., Zheng J. (2017), Decision Mechanism for Supplier Selection Under Sustainability, „International Journal of Information Technology, Decision Making”, Vol. 16, No. 1, pp. 87-115.

[27] Rorty R. (2005), Intuition, [in:] P. Edwards (ed.), The Encyclopedia of Philosophy, Macmillan, Vol. 4, New York - London.
[28] Simon H.A. (2013), Administrative Behavior, Simon and Schuster, New York.

[29] Sułkowski Ł. (2015), Management - from Epistemology by Methodology to Social Practice of Academia Cognitive Challenges in Management Science, „Przedsiebiorczość i Zarządzanie", Nr 16(2), s. 111-119.

[30] Wiecek-Janka E., Nowak M., Borowiec A. (2019), Application of the GDM Model in the Diagnosis of Crises in Family Businesses, „Grey Systems: Theory and Application”, Vol. 9, No. 11, pp. 114-127.

[31] Wierzbicki A.P. (1997), On the Role of Intuition in Decision Making and Some Ways of Multicriteria Aid of Intuition, „Journal of Multi-Criteria Decision Analysis", No. 6(2), pp. 65-76.

[32] Wierzbicki A.P. (2004), Knowledge Creation Theories and Rational Theory of Intuition, „International Journal for Knowledge and Systems Science”, No. 1(1), pp. 17-25.

[33] Wrzosek W. (2001), Strategie marketingowe, Szkoła Główna Handlowa w Warszawie, Warszawa.

[34] Zakeri S., Yang Y., Hashemi M. (2019), Grey Strategies Interaction Model, "Journal of Strategy and Management", Vol. 12, No. 1, pp. 30-60.

\section{Intuitive Solution \\ of Decision-making Problems Using the Grey Systems Theory}

\section{Summary}

The decision-making process is one of the basic theoretical issues in the management sciences. In recent years, particular importance is given to the analysis of the use of intuition in this process. Many well-known methods of making decisions are of little use in the case of high information uncertainty exemplified by three features: incompleteness of information, lack of information and the occurrence of information burdened with errors resulting from the subjectivism of decision-makers' assessments. This article is to answer the diagnosed niche. The aim of the article is to present the possibilities of using Grey Decision-Making Models in supporting decision-makers in the process of issuing intuitive decisions. The article presents the author's cluster-decision method enabling, among others, including in the decision-making process subjective, incomplete and low-grade assessments of experts that can be expressed using a linguistic scale. The method can be used in solving a number of management problems with high level of uncertainty. The first part of the article presents the basics of the theory of grey systems. The second part presents a formal mathematical model of the author's grey decision model. The third part presents the operation of the developed decision model on the example of the choice of a normative marketing strategy.

\section{Keywords}

epistemology of management, intuition, Grey Systems Theory, Grey Decision-Making Model 